\title{
Varicella-zoster Virus Pneumonia in an Immunocompetent Patient
}

Takeshi Saraya, Manami Inoue, Hajime Takizawa and Hajime Goto

Key words: varicella-zoster pneumonia, tiny nodules, immunocompetent patient, computed tomography

(Intern Med 52: 1003, 2013)

(DOI: 10.2169/internalmedicine.52.0150)

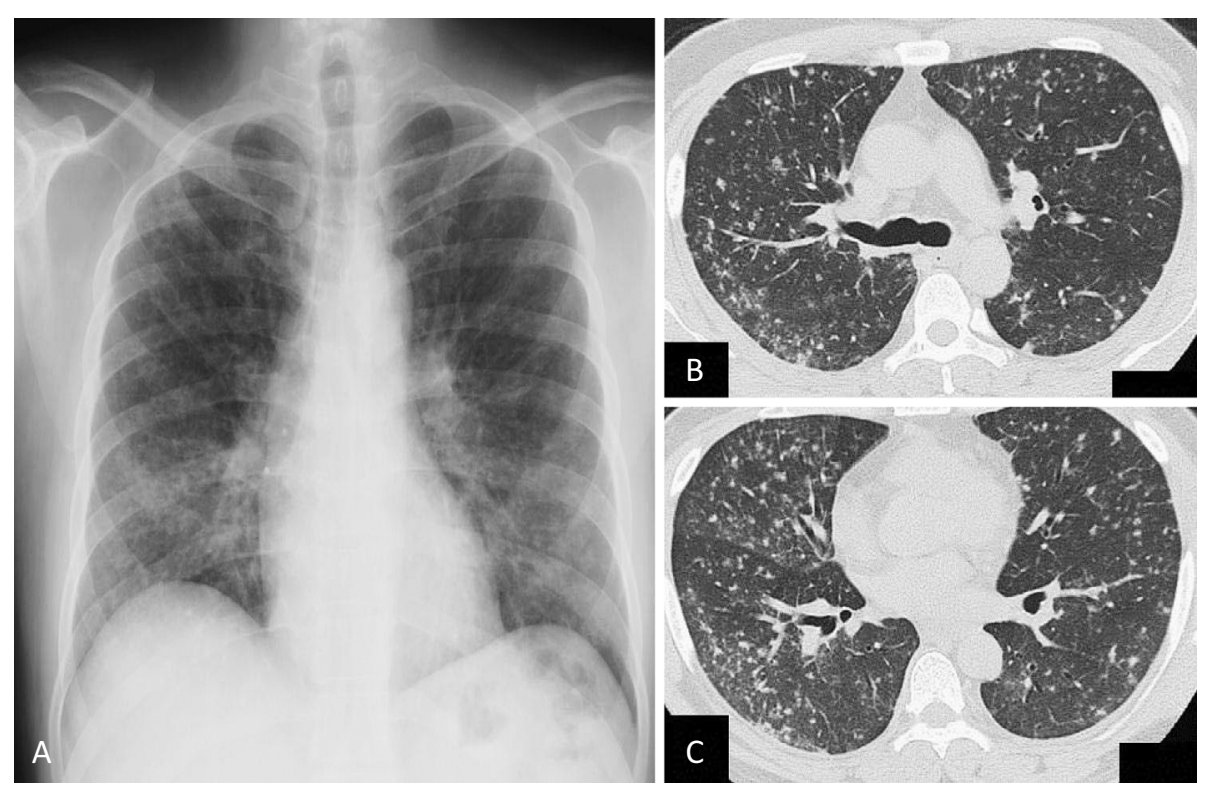

Picture.

A 47-year-old man presented at our hospital (day 1) with a five-day fever of $39^{\circ} \mathrm{C}$ and a vesicular skin rash on his face and trunk. He had no remarkable medical history, including chickenpox in his childhood. Two weeks prior to coming to our hospital, his child had suffered from chickenpox. The patient had oral aphtha and mild tachypnea of 22 breaths/min, although no hypoxemia was observed. Chest Xray and computed tomography showed tiny nodules primarily distributed over both middle to lower lung fields (Picture A), indicating transbronchial, lymphatic or hematological spread (Picture B, C). The serum titer of varicella-zoster virus (VZV) IgM (day 1) was positive at 7.69 on an enzyme immunoassay (EIA), and EIA titer increased from 2.6 (day 1) to 34.1 (day 22). The patient was thus diagnosed with VZV pneumonia. VZV pneumonia and herpes simplex virus pneumonia are extremely rare in immunocompetent patients and are well known for being associated with immunocompromised hosts. However, these diseases should also be considered in previously healthy patients $(1,2)$.

The authors state that they have no Conflict of Interest (COI).

\section{References}

1. Shirai T, Sano K, Matsuyama S, et al. Varicella pneumonia in a healthy adult presenting with severe respiratory failure. Intern Med 35: 315-318, 1996.

2. Miyazato A, Kishimoto H, Tamaki K, Nakama K, Saito A. Herpes simplex virus bronchopneumonia in a non-immunocompromized individual. Intern Med 40: 836-840, 2001.

Department of Respiratory Medicine, Kyorin University School of Medicine, Japan

Received for publication January 15, 2013; Accepted for publication January 20, 2013

Correspondence to Dr. Hajime Goto, h510@ks.kyorin-u.ac.jp

(C) 2013 The Japanese Society of Internal Medicine Journal Website: http://www.naika.or.jp/imonline/index.html 